\title{
Impact of Potassium Fertilization Rates and Potassium Solubilizing Bacteria Inoculation on The Growth, Yield and Quality Of Potato (Solanum Tuberosum L.)
}

\author{
Hassan A., Elkhatib ${ }^{1}$, Saed M. Gabr ${ }^{1}$. Ramadan A. Mohamed ${ }^{2}$ and Ahmed.F. Manaa ${ }^{2}$
}

\begin{abstract}
Two field experiments were conducted during the summer seasons of 2016 and 2017 at the Experimental Station Farm; South El- Tahrir; Horticultural Research Station, El- Behiera Governorate. This investigation aimed to study the effect of bio- fertilizer potassien(Bacillus circulance)in combination with different rates of mineral potassium fertilizer $\left(0,32,64\right.$ and $\left.96 \mathrm{kgK}_{2} \mathrm{O} / \mathrm{fed}\right)$ on the growth, yield and quality characters of potato CV. Spunta . Potassium fertilizer at 64 or $96 \mathrm{kgK}_{2} \mathrm{O} /$ fed with application of bio-K fertilizer promoted growth of potato and the highest mean value of plant height, number of leaves plant ${ }^{-}$ 1 , foliage fresh weight, leaves fresh weight, foliage dry weight, leaves dry weight , total chlorophyll and enhanced $N$, $P$ and $K$ uptake, as well as increased tuber weight ton/fed, average tuber weight and improved tubers quality characters expressed as dry matter, protein, starch, and total carbohydrates contents and specific gravity in the two seasons. It could be concluded that the interaction effect of inoculation potato tuber seeds with bio fertilizer at application of $67 \%(64 \mathrm{~kg} \mathrm{~K} 2 \mathrm{O} / \mathrm{fed})$ of the recommended $\mathrm{K}$ level $\left(96 \mathrm{~kg} \mathrm{~K}_{2} \mathrm{O} \mathrm{fed}{ }^{-1}\right)$ increased the productivity of potato tuber and improved tuber quality characteristics, as the same as $\left(96 \mathrm{~kg} \mathrm{~K}_{2} \mathrm{Ofed}^{-1}\right)$. In addition to saving about $33 \%$ of potato requirement of $K$ fertilizers and avoid environmental pollution hazards caused by excessive application of chemical fertilizers.
\end{abstract}

Key words: potatoes; potassium fertilization; Bacillus circulance; potassien

\section{INTRODUCTION}

Potato (Solanum tuberosum L.) is one of the most important foods and cash crops cultivated worldwide under a wide range of climatic conditions. According to FAO (2009), potato is the fourth most important food crop in terms of its production in the world, after wheat, rice and maize and potato is considered among the highly recommended food security crop that can safeguard low-income countries from the risks posed by rising international food prices FAO (2009). Nutrition analysis showed that potato is a healthy food in terms of vitamins, minerals, proteins, antioxidants, essential amino acids and carbohydrates (Andre et al., 2007). With the introduction of high yielding crop, Potato plants require much more potassium than many other

DOI: 10.21608/ASEJAIQJSAE.2019.29354

1. Horticulture Dept. Faculty of Agriculture, Damanhour Univ.

${ }^{2}$ Agriculture Research Center, Egypt.

Received February 16, 2019, Accepted March 28, 2019 vegetable crops; therefore it is also regarded as an indicator crop for $\mathrm{K}$ availability (Al-Moshileh and Errebi, 2004).

Potassium (K) is an essential macronutrient for plant growth and most abundantly absorbed cation in higher plants. As more than 90 per cent of potassium exists in the form of insoluble rock and silicate minerals (Parmar and Sindhu, 2013) and are available in very low amount to the plants and at the same time excessive use of chemical fertilizers causing the depletion of potassium from its reserve in faster rate. As a consequence, potassium deficiency is becoming one of the major constraints in crop production. Deficiency of potassium can lead to plants with poorly developed roots, low seed production, slow growth rate, and a lower yield and becoming one of the major constraints in crop production. This emphasized an essential need to find an alternative indigenous source of potassium for maintaining potassium status and plant uptake in soils for sustaining crop production (Kumar and Dubey, 2012).

Soil microbes have been reported to play a key role in the natural $\mathrm{K}$ cycle and could provide an alternative technology to make potassium available for uptake by plants (Rogers, 1998).Therefore, potassium solubilizing microorganisms present in the soil can conserve the existing resources and avoid environmental pollution hazards caused by heavy application of chemical fertilizers.

Potassium solubilizing bacteria which is of rhizosphere origin has the ability to solubilize insoluble form of potassium by different mechanism like production of capsular inorganic, polysaccharides along with organic acid like tartaric and oxalic acid that leads to solublization of feldspar and illite to release potassium (Sheng and $\mathrm{He}, 2006$ ). As reported by previous researchers, Inoculation of seeds and seedlings of different plants with KSB generally exerted beneficial effects on growth of eggplant, pepper, cucumber, Okra, brinjal and potato (Han and Lee, 2005; Han and Lee, 2006; Sangeeth et al., 2012; Prajapati et al., 2013; Ramarethinam and Chandra, 2006 and Abdel-Salam and Shams, 2012). These studies indicate that the use of 
KSB as bio-fertilizers for agriculture improvement can reduce the use of agrochemicals and support ecofriendly crop production (Archana et al., 2012).

The current experiment was, therefore, designed to carry out a field trial on the effect of potassium rates along with potassium solubilizing bacteria on the growth, yield and quality characters of potato.

\section{MATERIALS AND METHODS}

The field experiments of this investigation were carried out during the summer seasons of 2016 and 2017 at the experimental Station Farm; South El- Tahrir; Horticultural Research Station; El- Behiera Governorate under a drip irrigation system.

The mean goals of these experiments were to investigate the influence of minerals potassium and bio$\mathrm{K}$ fertilizer application and their combinations on vegetative growth characters, yield potentials and quality of potato plants (Solanum tuberosum L.) $C V$. Spunta

\section{Soil analyses of experimental sites:}

Prior of initiation of the experiments, samples of the top soil layer $(0-20 \mathrm{~cm})$ from each experimental site were collected, air dried, ground, sieved through a $2 \mathrm{~mm}$ sieve and then subjected to determine some soil chemical and physical properties according to (Page et al., 1982). These analyses were carried out at the Laboratory of Plant Nutrition Section; Soil Water and Environmental Research Institute. The results of these analyses are shown in Table (1).

\section{Treatments:}

\section{Mineral potassium fertilization:}

Four potassium rates were tested in this experiment $\left(0,32,64\right.$, and $96 \mathrm{~kg} \mathrm{~K}_{2} \mathrm{O}$ of potassium sulphate $(48 \%$ $\mathrm{K}_{2} \mathrm{O}$ ) /fed), which were added on two doses through the drip irrigation system (fertigation), the first one which represents $30 \%$ of the total amounts, was applied during the vegetative growth stage whereas the second portion; $70 \%$ of the total amounts was added during tuber initiation and bulking stage.

\section{Bacterial inoculation treatments:}

Potato (Solanum tuberosum L.) Seed pieces were surface-sterilized with sodium hypochlorite $(10 \% \mathrm{v} / \mathrm{v})$ for 8 min followed by extensive washing with sterilized distilled water. Potato seeds were inoculated by a commercial product of Agriculture Research Center called Potassien which contains Potassium Dissolving Bacteria (KDB) (Bacillus circulance) at the rats of 1200 $\mathrm{gm}$. fed ${ }^{-1}$. The inoculation process was performed by immersing the tuber seeds in potassien suspension containing 5\% Arabic gum as an adhesive agent for 15 minutes just before planting. The inoculation process was repeated three weeks later as a side dressing beside the seed pieces. Tuber seeds of the uninoculated control were dipped in distilled water containing 5\% Arabic gum for the same time (Ghoneim, 2005).

\section{Experimental layout:}

The Experimental layout was a split plot design in a randomized complete blocks with three replications, Potassium fertilizer rates were arranged as the main plots and the bio-fertilizer treatments were assigned as the sub-plots. The plot area was $8 \mathrm{~m}^{2}$, each plot had one row $0.8 \mathrm{~m}$ width and $10 \mathrm{~m}$ long and the distance between hills was $30 \mathrm{~cm}$ apart.

Potato tubers; $c v$ Spunta (imported from Holland) were used in the present investigation and obtained from Agric. Res. Center (ARC), Ministry of Agric.The tuber seeds were planted on the $5^{\text {th }}$ of February, during 2016 and 2017 seasons. Nitrogen fertilizer in the form of ammonium sulphate $(20.5 \% \mathrm{~N})$ and Ammonium nitrate $(33.5 \% \mathrm{~N})$ was added at the rate of $120 \mathrm{~kg} \mathrm{~N} / \mathrm{fed}$. Also, phosphorous fertilizer in the form of calcium super phosphate $(15.5 \% \mathrm{P})$ and Phosphoric acid $(80 \% \mathrm{P})$ was applied at the rate of $72 \mathrm{Kg} \mathrm{P}_{2} \mathrm{O}_{5} / \mathrm{fed}$. All Experimental plots received basal soil dressing, during soil preparation at the rate of $20 \mathrm{~kg} \mathrm{~N}$ as ammonium sulphate $(20.5 \% \mathrm{~N})$ and $40 \mathrm{~kg} \mathrm{P}_{2} \mathrm{O}_{5}$ as calcium super phosphate $(15.5 \% \mathrm{P})$. During the entire growing season the rest of nitrogen and phosphorus fertilizers were added through drip irrigation system three times per week at the rate of $100 \mathrm{~kg} \mathrm{~N} / \mathrm{fed}$ as Ammonium nitrate $(33.5 \% \mathrm{~N})$ and 32 $\mathrm{kg} \mathrm{P}_{2} \mathrm{O}_{5} /$ fed in the form of Phosphoric acid $(80 \% \mathrm{P})$. The injection of $\mathrm{N}, \mathrm{P}$ and $\mathrm{K}$ fertilizers, through the irrigation water, usually starts after 10 minutes from the beginning of irrigation period and stops few minutes before the termination of irrigation to insure the washing of irrigation lines.

Table1. Some chemical and physical characteristic of the soil used in the and 2016/2017 seasons

\begin{tabular}{|c|c|c|c|c|c|c|c|c|c|c|c|c|c|c|}
\hline \multirow[b]{3}{*}{ Season } & \multicolumn{4}{|c|}{ Physical properties } & \multicolumn{10}{|c|}{ chemical properties } \\
\hline & \multirow[t]{2}{*}{$\begin{array}{c}\text { Sand } \\
\%\end{array}$} & \multirow[t]{2}{*}{$\begin{array}{l}\text { Silt } \\
\%\end{array}$} & \multirow[t]{2}{*}{$\begin{array}{l}\text { Clay } \\
\%\end{array}$} & \multirow[t]{2}{*}{$\begin{array}{l}\text { Texture } \\
\text { Class }\end{array}$} & \multirow{2}{*}{$\begin{array}{c}\mathrm{EC} \\
\mathrm{dS} / \\
\mathrm{m}\end{array}$} & \multirow[t]{2}{*}{ PH } & \multicolumn{3}{|c|}{$\begin{array}{l}\text { Soluble cation } \\
\mathrm{mg} / \mathrm{L}\end{array}$} & \multicolumn{3}{|c|}{$\begin{array}{c}\text { Soluble anion } \\
\mathrm{mg} / \mathrm{L}\end{array}$} & \multirow[t]{2}{*}{$\begin{array}{l}\mathrm{N} \\
\%\end{array}$} & \multirow[t]{2}{*}{$\begin{array}{c}\mathrm{P} \\
\mathrm{ppm}\end{array}$} \\
\hline & & & & & & & $\mathrm{Ca}^{+}$ & $\mathrm{Mg}^{+}$ & $\mathrm{K}^{+}$ & $\mathrm{HcO}_{3}^{-}$ & $\mathrm{Cl}^{-}$ & $\mathrm{SO}_{4}^{--}$ & & \\
\hline $2015 / 2016$ & 93 & 4 & 3 & Sandy & 0.15 & 8.7 & 0.73 & 0.59 & 0.29 & 0.58 & 0.42 & 0.58 & 0.09 & 3.50 \\
\hline 2016/2017 & 94 & 5 & 1 & Sandy & 0.22 & 8.6 & 0.69 & 0.58 & 0.28 & 0.54 & 0.43 & 0.57 & 0.08 & 3.44 \\
\hline
\end{tabular}

experimental sites in $2015 / 2016$ 


\section{Data recorded:}

\section{Vegetative growth characters:}

Five randomly selected plants were taken from experimental unit at 90 days after planting. The following measurements were recorded: plant height, foliage fresh weight plant $^{-1}(\mathrm{~g})$, leaves fresh weight plant $^{-1}(\mathrm{~g})$, foliage dry weight plant $^{-1}(\mathrm{~g})$, leaves dry weight plant ${ }^{-1}(\mathrm{~g})$ and leaves area plant ${ }^{-1}\left(\mathrm{~cm}^{2}\right)$.

Photosynthetic pigments: $0.02 \mathrm{~g}$ of leaves was grounded in $80 \%$ acetone for the determination of chlorophyll a, chlorophyll b, total chlorophyll contents and carotenoid contents according to Lichtenthaler (1987).

Plant chemical analysis: From the same plant sample taken for recording the vegetative features, random samples of the youngest expanded mature leaves were collected, washed with distilled water, weighed, oven dried at $70{ }^{\circ} \mathrm{C}$ till constant weight. The dried leaf materials were grind and homogenized, wet digested; using concentrated sulfuric acid and $\mathrm{H}_{2} \mathrm{O}_{2}$, and the contents of $\mathrm{N}, \mathrm{P}$ and $\mathrm{K}$ were determined as follows:

Nitrogen content (\%): Nitrogen percentage in leaves was determined by micro kjeldahl method according to Page et al. (1982).

Phosphorus content (\%): Phosphorus was determined colorimetrically as described by Singh et al. (2005).

Potassium content (\%): Potassium was determined by flame photometer as illustrated by Horneck and Hanson (1998).

Tuber Yield and its components: Harvest was carried out 110 days after planting. The harvested tubers were weighed, counted and the following characters were calculated: The number of tubers plant ${ }^{-1}$, tuber weight (g) plant ${ }^{-1}$, tuber yield plant ${ }^{-1}(\mathrm{~g})$ and total tubers yield per fed ${ }^{-1}$ (ton)

Tubers quality characters: Tuber samples from each subplot was saved to determine total carbohydrates content as outlined by (Malik and Singh, 1980), tuber dry matter content, tuber specific gravity was determined from the raw tubers as follows: Specific gravity $\left(\mathrm{g} / \mathrm{cm}^{3}\right)=$ Tuber mass $(\mathrm{g}) /$ tuber volume $\left(\mathrm{cm}^{3}\right)$ as described by Dinesh et al. (2005) and Tuber reducing sugars content (\%): determined calorimetrically, according to the method of Dubois et al. (1956).

Statistical Analysis: All obtained data of the present study were, statistically, analyzed according to the design applied using (Costat software, 1985). The comparisons among means of the different treatments were carried out, using the Revised L.S.D. test as illustrated by El-Rawy and Khalf- Allah (1980).

\section{RESULTS AND DISCUSSION}

\section{Vegetative growth characters:}

\section{Effect of potassium:}

Vegetative growth of potato plants were significantly affected by potassium (K) treatments in both seasons (Table 2). The gradual increase of potassium application up to $96 \mathrm{~kg} \mathrm{~K}_{2} \mathrm{O}$ fed $^{-1}$, resulted in significant increase on all vegetative growth characters compared to control treatment i.e. plant height, number of leaves plant ${ }^{-1}$, foliage fresh weight, leaves fresh weight plant $^{-1}$, foliage dry weight, Leaves dry weight and leaves area on both seasons of study. Such a positive effect of Potassium could be explained on the ground that potassium plays an important role in plant growth and development. Its role is well documented in photosynthesis, increasing enzyme activity, improving synthesis of protein, carbohydrates and fats, translocation of photosynthetic materials, enabling their ability to resist pests and diseases. Also, potassium is considered as a major somatically active cation of plant cell Mehdi et al. (2007). Moreover potassium is an important nutrient for plant meristematic growth and physiological functions, including regulation of water and gas exchange in plants, protein synthesis, enzyme activation, and photosynthesis and carbohydrate translocation in plants. Potassium has favorable effects on metabolism of nucleic acids, proteins, vitamins and growth substances Bednarz and Oosterhuis (1999). These results are in general agreed with those reported by Elhakim et al. (2016) found that, increasing Potassium fertilizer up to100 Kg Fed- ${ }^{1}$ gave the highest mean value of vegetative growth characters of potato plants. Also, Helal and Abd Elhady (2015) indicated that, the level of 50 and $75 \quad \mathrm{~K}_{2} \mathrm{O} \quad \mathrm{Fed}^{-1}$ improved plant growth significantly of potato in both seasons. Al-Moshileh et al. (2005) reveled that increasing potassium sulfate rates resulted in a significant increase of plant height and leaf area of potato plants.

\section{Effect of bio-K fertilizer:}

The effects of (potassien) on vegetative growth characters of potato plants in both seasons are showed in (Table 2). Potassien inoculated plants showed significant increments in all the studied vegetative growth characters; plant height, number of leaves plant ${ }^{-}$ ${ }^{1}$, foliage fresh weight, leaves fresh weight, foliage dry weight, leaves dry weight and leaves area on both seasons compared to uninoculated ones in both seasons. The enhancing effect of potassium dissolving bacteria inoculation on plant growth may be attributed to its beneficial effects on the solubilization processes of silicate minerals (Deka and Dutta, 2000 and Marschner, 1997). 
Table 2.The main effects of potassium rates and bio- $\mathrm{k}$ fertilizer on the vegetative growth characters of potato plants during 2016 and 2017 seasons

\begin{tabular}{|c|c|c|c|c|c|c|c|c|c|c|c|c|c|c|c|}
\hline \multirow{2}{*}{\multicolumn{2}{|c|}{ Treatments }} & \multicolumn{2}{|c|}{$\begin{array}{l}\text { Plant height } \\
\text { (cm) }\end{array}$} & \multicolumn{2}{|c|}{$\begin{array}{l}\text { Number of } \\
\text { leaves plant }^{-1}\end{array}$} & \multicolumn{2}{|c|}{$\begin{array}{c}\text { Foliage } \\
\text { fresh weight } \\
\text { (g) }\end{array}$} & \multicolumn{2}{|c|}{$\begin{array}{c}\text { Leaves } \\
\text { fresh Weight (g) }\end{array}$} & \multicolumn{2}{|c|}{$\begin{array}{l}\text { foliage dry weight } \\
\text { (g) }\end{array}$} & \multicolumn{2}{|c|}{$\begin{array}{c}\text { Leaves } \\
\text { dry weight } \\
\text { (g) }\end{array}$} & \multicolumn{2}{|c|}{$\begin{array}{l}\text { Leaf area plant } \\
\qquad\left(\mathrm{cm}^{-1}\right)\end{array}$} \\
\hline & & 2016 & 2017 & 2016 & 2017 & 2016 & 2017 & 2016 & 2017 & 2016 & 2017 & 2016 & 2017 & 2016 & 2017 \\
\hline \multirow{5}{*}{ 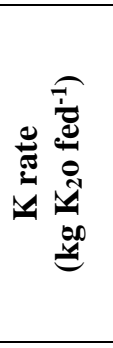 } & $\mathbf{0}$ & $\mathrm{C}$ & $\mathrm{C}$ & $\mathrm{D}$ & $\mathrm{D}$ & $7 \mathrm{D}$ & $\mathrm{D}$ & $\mathrm{D}$ & $\mathrm{D}$ & $\mathrm{D}$ & $\mathrm{D}$ & $\mathrm{D}$ & $\mathrm{D}$ & $\mathrm{D}$ & $\mathrm{D}$ \\
\hline & \multirow{2}{*}{32} & 72.31 & 70.06 & 41.34 & 46.86 & 354.9 & 353.40 & 242.6 & 241.63 & 41.30 & 47.73 & 34.07 & 39.61 & 4920.5 & 4748.6 \\
\hline & & B & B & $\mathrm{C}$ & $\mathrm{C}$ & $5 \mathrm{C}$ & $\mathrm{C}$ & $\mathrm{C}$ & $\mathrm{C}$ & $\mathrm{C}$ & $\mathrm{C}$ & $\mathrm{C}$ & $\mathrm{C}$ & $\mathrm{C}$ & $\mathrm{C}$ \\
\hline & 64 & 79.71 & 78.18 & 46.18 & 52.62 & 438.5 & 440.87 & 295.8 & 296.98 & 52.50 & 61.53 & 42.98 & 50.64 & 6058.9 & 5879.8 \\
\hline & 96 & A & $\mathrm{A}$ & A & A & $2 \mathrm{~A}$ & A & $\mathrm{A}$ & A & $\mathrm{A}$ & A & $\mathrm{A}$ & A & A & A \\
\hline \multirow{4}{*}{ 赵 } & \multirow{2}{*}{ UnInoculated } & 68.53 & 67.53 & 37.88 & 44.14 & 342.5 & 350.04 & 231.3 & 237.22 & 37.52 & 44.63 & 30.49 & 36.64 & 4681.7 & 4644.8 \\
\hline & & B & $\mathrm{B}$ & $\mathrm{B}$ & B & $6 \mathrm{~B}$ & B & $\mathrm{B}$ & B & B & B & B & B & B & B \\
\hline & \multirow{2}{*}{ Inoculated } & 74.85 & 72.45 & 45.69 & 50.86 & 417.0 & 409.3 & 283.1 & 277.55 & 50.67 & 58.69 & 41.87 & 48.78 & 5808.3 & 5472.8 \\
\hline & & A & A & A & A & $5 \mathrm{~A}$ & A & A & A & A & A & A & A & A & A \\
\hline
\end{tabular}

Values having a common alphabetical letter (s), do not significant differ using the revised L.S.D. test at 0.05 . 
Tables 3.The interaction effects between potassium and bio- $\mathrm{K}$ fertilizer on the vegetative growth characters of potato plants during 2016 and 2017 seasons

\begin{tabular}{|c|c|c|c|c|c|c|c|c|c|c|c|c|c|c|c|}
\hline \multicolumn{2}{|c|}{$\begin{array}{l}\text { Characters } \\
\text { Treatments }\end{array}$} & \multicolumn{2}{|c|}{$\begin{array}{l}\text { Plant height } \\
\text { (cm) }\end{array}$} & \multicolumn{2}{|c|}{$\begin{array}{l}\text { Number of } \\
\text { leaves plant }^{-1}\end{array}$} & \multicolumn{2}{|c|}{$\begin{array}{c}\text { foliage } \\
\text { fresh Weight } \\
(\mathrm{g})\end{array}$} & \multicolumn{2}{|c|}{$\begin{array}{l}\text { Leaves Fresh } \\
\text { Weight (g) }\end{array}$} & \multicolumn{2}{|c|}{$\begin{array}{c}\text { foliage dry weight } \\
\text { (g) }\end{array}$} & \multicolumn{2}{|c|}{$\begin{array}{c}\text { Leaves } \\
\text { dry Weight } \\
\text { (g) }\end{array}$} & \multicolumn{2}{|c|}{$\begin{array}{l}\text { Leaf area plant } \\
\qquad\left(\mathrm{cm}^{2}\right)\end{array}$} \\
\hline $\begin{array}{c}\mathrm{K}_{20} \\
(\mathrm{~kg} / \mathrm{fed})\end{array}$ & Bio-K & 2016 & 2017 & 2016 & 2017 & 2016 & 2017 & 2016 & 2017 & 2016 & 2017 & 2016 & 2017 & 2016 & 2017 \\
\hline \multirow{4}{*}{0} & Without & 52.6 & 51.82 & 29.99 & 34.77 & 239.64 & 242.17 & 163.86 & 166.7 & 23.44 & 28.36 & 19.12 & 23.64 & 3290.1 & $\overline{3247.3}$ \\
\hline & Bio-K & $\mathrm{G}$ & G & $\mathrm{G}$ & $\mathrm{F}$ & $\mathrm{H}$ & F & E & $8 \mathrm{D}$ & $\mathrm{F}$ & $\mathrm{G}$ & $\mathrm{F}$ & $\mathrm{F}$ & $\mathrm{H}$ & $\mathrm{G}$ \\
\hline & With Bio- & 55.82 & 54.43 & 34.92 & 38.99 & 287.90 & 281.32 & 198.72 & 193.6 & 31.00 & 36.96 & 25.87 & 31.18 & 4044.2 & 3700.9 \\
\hline & K & $\mathrm{F}$ & $\mathrm{F}$ & $\mathrm{F}$ & $\mathrm{E}$ & $\mathrm{G}$ & E & $\mathrm{D}$ & $7 \mathrm{CD}$ & $\mathrm{E}$ & $\mathrm{F}$ & $\mathrm{E}$ & E & $\mathrm{G}$ & $\mathrm{F}$ \\
\hline \multirow{4}{*}{32} & Without & 68.88 & 67.52 & 37.07 & 43.26 & 312.63 & 319.94 & 213.02 & 218.9 & 34.22 & 40.21 & 27.99 & 33.1 & 4286.7 & 4269.2 \\
\hline & Bio-K & E & $\mathrm{E}$ & E & $\mathrm{D}$ & F & $\mathrm{D}$ & $\mathrm{D}$ & $3 \mathrm{C}$ & $\mathrm{D}$ & E & $\mathrm{D}$ & $\mathrm{D}$ & F & E \\
\hline & With Bio- & 75.74 & 72.61 & 45.62 & 50.48 & 397.27 & 386.87 & 271.5 & 260.3 & 48.39 & 55.27 & 40.17 & 46.13 & 5554.3 & 5228.0 \\
\hline & K & $\mathrm{C}$ & $\mathrm{D}$ & $\mathrm{B}$ & $\mathrm{B}$ & $\mathrm{D}$ & $\mathrm{C}$ & $\mathrm{C}$ & $4 \mathrm{~B}$ & B & $\mathrm{C}$ & B & B & D & $\mathrm{D}$ \\
\hline \multirow{4}{*}{64} & Without & 75.15 & 74.68 & 41.07 & 48.11 & 383.72 & 395.81 & 258.69 & 272.1 & 43.04 & 51.54 & 34.99 & 42.23 & 5253.9 & 5235.4 \\
\hline & Bio-K & $\mathrm{D}$ & $\mathrm{C}$ & $\mathrm{D}$ & $\mathrm{C}$ & E & $\mathrm{C}$ & $\mathrm{C}$ & $9 \mathrm{~B}$ & $\mathrm{C}$ & $\mathrm{D}$ & $\mathrm{C}$ & $\mathrm{C}$ & E & $\mathrm{D}$ \\
\hline & With Bio- & 84.28 & 81.70 & 51.29 & 57.15 & 493.44 & 485.94 & 332.48 & 326.7 & 61.97 & 71.52 & 50.99 & 59.05 & 6864.0 & 6524.1 \\
\hline & K & A & $\mathrm{A}$ & $\mathrm{A}$ & A & $\mathrm{A}$ & $\mathrm{A}$ & A & $9 \mathrm{~A}$ & A & $\mathrm{A}$ & A & A & A & A \\
\hline \multirow{4}{*}{96} & Without & 77.52 & 76.13 & 43.40 & 50.44 & 434.26 & 442.24 & 289.53 & 296.0 & 49.39 & 58.42 & 39.88 & 47.61 & 5896.1 & $\overline{5827.1}$ \\
\hline & Bio-K & B & B & $\mathrm{C}$ & B & $\mathrm{C}$ & B & B & $1 \mathrm{~B}$ & B & $\mathrm{B}$ & B & B & C & $\mathrm{C}$ \\
\hline & With Bio- & 83.57 & 81.07 & 50.92 & 56.85 & 489.60 & 483.3 & 329.88 & 325.4 & 61.36 & 71.04 & 50.47 & 58.77 & 6770.4 & 6438.0 \\
\hline & K & A & A & A & A & B & A & A & A & A & A & $\mathrm{A}$ & A & B & $\mathrm{B}$ \\
\hline
\end{tabular}

*Values having a common alphabetical letter (s), do not significant differ using the revised L.S.D. test at 0.05 
They added also that these microorganismssolubilize $\mathrm{K}$ - bearing minerals to free $\mathrm{K}$ for plants. This solubilization effect is generally due to the production of certain organic acids and enzymes by KDB. In addition, they are also known to produce amino acids, vitamins and growth promoting substances like indole-3-acetic acid (IAA) and gibberellic acid $\left(\mathrm{GA}_{3}\right)$ which help in better growth of the plants Ponmurugan and Gopi (2006). These results are in agreement with those found by Lynn et al. (2013) who observed that increments in tomato biomass and $\mathrm{K}$ uptake estimated by 125 and 150 $\%$ respectively due to inoculation of silicate-dissolving bacteria as compared to un-inoculated plants. Also, Prajapati et al. (2013) found that inoculation of potassium-releasing bacteria Enterobacter hormaechei and fungi Aspergillus terreus increased the root and shoot growth of okra, and both microorganisms were able to mobilize potassium efficiently in plants.

\section{Interaction effects between potassium and bio-K fertilizer:}

Table (3) showed that there were significant interaction effects between potassium rates and bio-K fertilizer on all the studied vegetative growth parameters i.e. Plant height, number of leaves plant ${ }^{-1}$, foliage fresh weight, leaves fresh weight, foliage dry weight, leaves dry weight and Leaves area compared to control treatment in the two seasons. The favoring effect of inoculation with bio-K fertilizer on vegetative growth characters, varied according to the used potassium level. The combined treatment, which included potassium rates of 64 or $96 \mathrm{~kg} \mathrm{~K} \mathrm{fed}^{-1}$ and bio K-fertilizer gave higher mean values of all the studied growth characters, in both seasons except the leaves area which showed higher values by $\mathrm{K}$ application rate of 64 than $96 \mathrm{~K}_{2} \mathrm{O}$ $\mathrm{fed}^{-1}$. Similar conclusions were previously recorded on potato plants by Mohammadi et al., (2013); Elhakim et al. (2016); Janmohammadi et al. (2016) and Ahmed et al. (2009).

\section{Photosynthetic Pigments:}

\section{Effect of potassium:}

Table (4) showed the effects of various potassium rates on chlorophyll $a$, chlorophyll $b$, chlorophyll $a+b$ and carotene contents were significant relative to the uninoculated treatment and the trend was approximately similar, on both seasons. The gradual addition of $\mathrm{K}$ up to $96 \mathrm{~kg} \mathrm{~K}_{2} \mathrm{O}$ fed ${ }^{-1}$, resulted in significant increments of chlorophyll a, chlorophyll $\mathrm{a}+\mathrm{b}$ and carotene contents of potato plants on both seasons compared to the control treatment. However, the statistical comparisons among the different $\mathrm{K}$ rates showed that the highest two levels (64 and $96 \mathrm{kgK}_{2} \mathrm{fed}^{-1}$ ) appeared to be sufficient for the plants to express the highest chlorophyll $\mathrm{b}$ content in leaves of potato plants on both seasons. Wang et al. (2013) and Salami and Saadat (2013) pointed out that K plays an essential role for many processes needed to sustain plant growth and reproduction i.e. photosynthesis, translocation of photosynthesis products. Similar result was reported by Abd El-Latif $e t$ al. (2011) working on potato plants who found that increasing potassium rates had a significant effect on chlorophyll and carotenoid contents. Also, Singh and Lal (2012) demonstrated that Chl a, Chl b and carotenoid increased significantly by increasing potassium fertilization up to $100 \mathrm{~kg} \mathrm{~K}_{2} \mathrm{O} \mathrm{ha}{ }^{-1}$.

\section{Effect of bio-fertilizer:}

Table (4) indicated that inoculated potato plants with the bio- Potassium fertilizer (potassien) was superior compared to uninoculated plants in terms of chlorophyll $\mathrm{a}$, chlorophyll $\mathrm{b}$, chlorophyll $\mathrm{a}+\mathrm{b}$ and carotene content on both seasons. Such promoting effects of biofertilization on photosynthetic pigments might be attributed to its stimulating effects on vegetative growth, photosynthetic pigments and mineral contents, which in turn, reflected positively on photosynthetic pigments on tomato plants Barakat and Gabr (1998). Similar results were also obtained by Gabr et al. (2001) and Fawzy et al. (2012) working on sweet pepper.

\section{Interaction effects between potassium and bio-K fertilizer:}

Table (5) indicated that fertilizing potato plants with 64 or $96 \mathrm{~kg} \mathrm{~K}_{2} \mathrm{O}$ fed $^{-1}$ plus inoculated potato with bio-K (potassien) was responsible for the Increasing values of all pigment traits on both seasons. The same trend was recorded by Ahmed et al. (2009) who found that the highest photosynthetic pigment values were recorded with potato plants which received potassein as bio-K fertilizer at the level $(3 \mathrm{~L} / \mathrm{fed})$ combined with potassium sulphate as mineral-K fertilizer at the level (90 kg KO $/$ /fed) in both seasons. This trend was also obtained by (El-Banna and Tolba (2000); Elhakim et al. (2016) and El-Shimi et al. (2002). who reported that application of $\mathrm{K}$ rates and bio-K fertilizer significantly increased photosynthetic pigment values. 
Tables 4.The main effects of potassium rates and bio- $\mathrm{k}$ fertilizer on pigment of photosynthesis content of potato plants during 2016 and 2017 seasons

\begin{tabular}{|c|c|c|c|c|c|c|c|c|c|}
\hline \multirow[b]{2}{*}{ Treatments } & \multirow[t]{2}{*}{ Characters } & \multicolumn{2}{|c|}{ Chlorophyll a(mg/g) } & \multicolumn{2}{|c|}{ Chlorophyll b (mg/g) } & \multicolumn{2}{|c|}{ Chlorophyll a+b (mg/g) } & \multicolumn{2}{|c|}{ Carotenoids (mg/g) } \\
\hline & & 2016 & 2017 & 2016 & 2017 & 2016 & 2017 & 2016 & 2017 \\
\hline \multirow{4}{*}{ 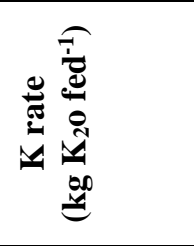 } & $\mathbf{0}$ & $0.842 \mathrm{~B}$ & $0.799 \mathrm{D}$ & $0.258 \mathrm{C}$ & $0.273 \mathrm{C}$ & $1.101 \mathrm{D}$ & $1.072 \mathrm{D}$ & $0.646 \mathrm{D}$ & $0.606 \mathrm{D}$ \\
\hline & 32 & $1.021 \mathrm{C}$ & $0.962 \mathrm{C}$ & $0.313 \mathrm{~B}$ & $0.321 \mathrm{~B}$ & $1.335 \mathrm{C}$ & $1.284 \mathrm{C}$ & $0.811 \mathrm{C}$ & $0.749 \mathrm{C}$ \\
\hline & 64 & $1.103 \mathrm{~B}$ & $1.027 \mathrm{~B}$ & $0.334 \mathrm{~A}$ & $0.344 \mathrm{~A}$ & $1.438 \mathrm{~B}$ & $1.371 \mathrm{~B}$ & $0.897 \mathrm{~B}$ & $0.830 \mathrm{~B}$ \\
\hline & 96 & $1.124 \mathrm{~A}$ & $1.048 \mathrm{~A}$ & $0.341 \mathrm{~A}$ & $0.351 \mathrm{~A}$ & $1.466 \mathrm{~A}$ & $1.399 \mathrm{~A}$ & $0.924 \mathrm{~A}$ & $0.853 \mathrm{~A}$ \\
\hline \multirow{2}{*}{ 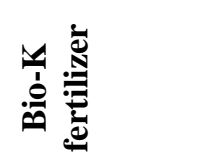 } & Uninoculated & $0.990 \mathrm{~B}$ & $0.884 \mathrm{~B}$ & $0.254 \mathrm{~B}$ & $0.305 \mathrm{~B}$ & $1.245 \mathrm{~B}$ & $1.189 \mathrm{~B}$ & $0.750 \mathrm{~B}$ & $0.702 \mathrm{~B}$ \\
\hline & inoculated & $1.055 \mathrm{~A}$ & $1.034 \mathrm{~A}$ & $0.369 \mathrm{~A}$ & $0.340 \mathrm{~A}$ & $1.425 \mathrm{~A}$ & $1.374 \mathrm{~A}$ & $0.889 \mathrm{~A}$ & $0.817 \mathrm{~A}$ \\
\hline
\end{tabular}

*Values having a common alphabetical letter (s), do not significant differ using the revised L.S.D. test at 0.05 .

Tables 5.The interaction effects between potassium and bio- $\mathrm{K}$ fertilizer on pigment of photosynthesis content of potato plants during 2016 and 2017 seasons

\begin{tabular}{|c|c|c|c|c|c|c|c|c|c|}
\hline \multirow{2}{*}{$\begin{array}{c}\text { Treatments } \\
K_{20}(\mathrm{~kg} / \mathrm{fed}) \\
\end{array}$} & \multirow{2}{*}{$\begin{array}{l}\text { Characters } \\
\text { Bio-K }\end{array}$} & \multicolumn{2}{|c|}{$\begin{array}{c}\text { Chlorophyll a } \\
\text { (mg/g) }\end{array}$} & \multicolumn{2}{|c|}{$\begin{array}{c}\text { Chlorophyll b } \\
\text { (mg/g) }\end{array}$} & \multicolumn{2}{|c|}{$\begin{array}{c}\text { Chlorophyll a+b } \\
(\mathrm{mg} / \mathrm{g})\end{array}$} & \multicolumn{2}{|c|}{$\begin{array}{c}\text { Carotenes } \\
(\mathrm{mg} / \mathrm{g})\end{array}$} \\
\hline & & 2016 & 2017 & 2016 & 2017 & 2016 & 2017 & 2016 & 2017 \\
\hline \multirow{3}{*}{$\mathbf{0}$} & Without Bio & $0.835 \mathrm{D}$ & $0.759 \mathrm{E}$ & $0.220 \mathrm{C}$ & $0.267 \mathrm{D}$ & $1.055 \mathrm{E}$ & $1.026 \mathrm{E}$ & $0.609 \mathrm{E}$ & $0.575 \mathrm{E}$ \\
\hline & With Bio-K & $0.8502 \mathrm{D}$ & $0.841 \mathrm{DE}$ & $0.297 \mathrm{BC}$ & $0.279 \mathrm{D}$ & 1.147 DE & 1.120 DE & $0.684 \mathrm{DE}$ & $0.639 \mathrm{DE}$ \\
\hline & Without Bio-K & $0.980 \mathrm{C}$ & $0.880 \mathrm{CD}$ & $0.256 \mathrm{C}$ & $0.302 \mathrm{CD}$ & $1.236 \mathrm{CD}$ & $1.182 \mathrm{CD}$ & $0.736 \mathrm{CDE}$ & $0.690 \mathrm{CDE}$ \\
\hline \multirow[t]{2}{*}{32} & With Bio-K & $1.063 \mathrm{~B}$ & $1.045 \mathrm{~B}$ & $0.371 \mathrm{~B}$ & $0.342 \mathrm{BC}$ & $1.434 \mathrm{~B}$ & $1.387 \mathrm{~B}$ & $0.887 \mathrm{~B}$ & $0.809 \mathrm{BC}$ \\
\hline & Without Bio-K & $1.0481 \mathrm{BC}$ & $0.925 \mathrm{CD}$ & $0.264 \mathrm{C}$ & $0.317 \mathrm{BCD}$ & $1.312 \mathrm{BC}$ & $1.242 \mathrm{CD}$ & $0.804 \mathrm{BCD}$ & $0.751 \mathrm{BCD}$ \\
\hline \multirow[t]{2}{*}{64} & With Bio-K & $1.159 \mathrm{~A}$ & $1.129 \mathrm{~A}$ & $0.406 \mathrm{~A}$ & $0.371 \mathrm{~A}$ & $1.565 \mathrm{~A}$ & $1.500 \mathrm{~A}$ & $0.991 \mathrm{~A}$ & $0.910 \mathrm{AB}$ \\
\hline & Without Bio-K & $1.099 \mathrm{~B}$ & $0.973 \mathrm{BC}$ & $0.279 \mathrm{BC}$ & $0.336 \mathrm{BC}$ & $1.379 \mathrm{~B}$ & $1.308 \mathrm{BC}$ & $0.855 \mathrm{BC}$ & $0.795 \mathrm{BCD}$ \\
\hline 96 & With Bio-K & $1.150 \mathrm{~A}$ & $1.124 \mathrm{~A}$ & $0.404 \mathrm{~A}$ & $0.368 \mathrm{AB}$ & $1.554 \mathrm{~A}$ & $1.492 \mathrm{~A}$ & $0.995 \mathrm{~A}$ & $0.911 \mathrm{~A}$ \\
\hline
\end{tabular}




\section{Chemical contents of leaves and tuber: Effect of potassium:}

Table (6) cleared that the application of $\mathrm{K}$ fertilizer caused significant increases on $\mathrm{N}, \mathrm{P}$ and $\mathrm{K}$ contents of leaves and tubers relative to the control treatment. The highest rate of $\mathrm{K}\left(96 \mathrm{~kg} \mathrm{~K}_{2} \mathrm{O}\right.$ fed $\left.^{-1}\right)$ produced the highest mean values of $\mathrm{N}, \mathrm{P}$ and $\mathrm{K}$ contents of leaves and tubers on both seasons. Adding $96 \mathrm{~kg} \mathrm{~K}_{2} \mathrm{O}$ fed $^{-1}$ have resulted in 52.4and $49.0 \%, 74.3$ and $79.2 \%, 42.4$ and $40.3 \%$ increments in the first and the second seasons for $\mathrm{N}, \mathrm{P}$ and $\mathrm{K}$ content of potato leaves respectively, meanwhile the corresponding increased values in the first and the second seasons for $\mathrm{N}, \mathrm{P}$ and $\mathrm{K}$ content of potato tuber were 27.7 and $27.7 \%, 112.5$ and $110.8 \%, 57.6$ and $56.3 \%$, respectively. These results agreed with those of Elhakim et al. (2016) who found that significant increases of nitrogen and potassium contents when potato plants received potassium fertilization at the rates 60 or $120 \mathrm{~kg} \mathrm{~K}_{2} \mathrm{O} \mathrm{fed}^{-1}$. Also, Singh and Bansal (2000) reported that application of different sources of potassium gave the highest values of $\mathrm{N}, \mathrm{P}$ and $\mathrm{K}$ content of potato plant compared to control treatment. Similar findings on the mineral contents of potato plants were reported by El-Sayed et al. (2014) who stated that potassium fertilizer significantly improved leaves content of phosphorus $(\mathrm{P})$ and potassium $(\mathrm{K})$ of potato plants. Moreover, Abou zeid and Abd El-Latif (2017) found that nitrogen $(\mathrm{N})$, phosphorus $(\mathrm{P})$ and potassium (K) contents of potato plants increased with increasing potassium rates up to $120 \mathrm{~kg} \mathrm{~K}_{2} \mathrm{O}$ fed $^{-1}$. Wallingford (1980) mentioned that potassium is involved in the activation of more than 60 enzymes, which are necessary for essential plant processes such as energy utilization, starch synthesis and $\mathrm{N}$ metabolism and respiration.

\section{Effect of bio-K fertilizer:}

The inoculation of potato plants with bio-K (potassien) fertilizer was significantly associated with the higher contents of $\mathrm{N}, \mathrm{P}$ and $\mathrm{K}$ contents of leaves and tubers relative to the un-inoculated plants on both seasons Table (6). The increments of $\mathrm{N}, \mathrm{P}$, and $\mathrm{K}$ content in leaves were 28.8 and $12.8 \%, 14.4$ and $27.7 \%$, 13.7 and $17.2 \%$ in the first and the second seasons respectively. On the other hand the increments of elemental contents in tube were 17.1 and $16.7 \%, 16.8$ and $18.9 \%$ and 28.7 and $26.7 \%$ in the first and the second seasons for $\mathrm{N}, \mathrm{P}$, and $\mathrm{K}$ content respectively. Similar results were reported by Xue et al. (2000) and Sheng et al. (2003) who found that K dissolving bacteria could improve soil $\mathrm{P}$ and $\mathrm{K}$ reserves and promoted plant growth . Also, Lin et al. (2002) recorded increases of K and $\mathrm{P}$ content of tomato plant by $125 \%$ and $150 \%$ respectively, compared to non-inoculated plants due to inoculation of potassium dissolving bacteria (Bacillus mucilaginosus). Similarly Afify and Bayoumy (2001) reported that the increase in tubers potassium content might be possibly due to the role of microorganisms in supplying great amounts of both water-soluble and amorphous potassium which was reflected in plant uptake.

\section{Interaction effects between potassium and bio-K fertilizer:}

Table (7) indicated that the interaction between the used different $\mathrm{K}$ fertilizer rates and bio- $\mathrm{K}$ (potassien) had significant effect on N, P and $\mathrm{K}$ contents of leaves and tubers. The highest mean value for $\mathrm{N}, \mathrm{P}$ and $\mathrm{K}$ contents of leaves and tubers were obtained when potassium were applied at the rate of 96 or $64 \mathrm{~kg} \mathrm{~K}_{2} \mathrm{O}$ $\mathrm{fed}^{-1}$ in combined with bio-K (potassien) inoculation on both seasons. Similar trend was reported by (Ahmed $e t$ al., 2009) who indicated that the highest chemical contents of leaves and tuber were recorded with potato plants which received potassein as bio-K fertilizer at the level $\left(3 \mathrm{~L} \mathrm{fed}^{-1}\right)$ combined with potassium sulphate as mineral-K fertilizer at the level of $90 \mathrm{~kg} \mathrm{~K}_{2} \mathrm{O}$ fed $^{-1}$ In both seasons. Also, (Badr et al., 2006) found that application of KDB with $\mathrm{K}$ - and P-bearing minerals on sorghum enhanced phosphorus uptake by $71 \%, 110 \%$, and $116 \%$; and $\mathrm{K}$ uptake by $41 \%, 93 \%$, and $79 \%$ in clay, sandy, and calcareous soils, respectively.

\section{Tuber yield and its components:}

\section{Effect of potassium:}

Table (8) showed that application of the highest $\mathrm{K}$ application level $\left(96 \mathrm{Kg} \mathrm{K}_{2} \mathrm{O}\right.$ fed $^{-1}$ ), caused significant increments relative to the control estimated by 53.7, 14.9 and $33.7 \%$ in the first season, and by $52.6,16.2$ and $31.3 \%$, in the second season, respectively, in tuber yield plant ${ }^{-1}$, number of tuber plant ${ }^{-1}$, and average tuber weight of potato plants . In a similar study Adhikary and Karki (2006) showed that increasing K application had increased tuber yield. This is because; higher application of $\mathrm{K}$ facilitates the crop to have better nutrients and water absorption that improve growth and development of the crop and ultimately tuber yield. An increase in potato yield as illustrated in the present investigation due to applying potassium was reported by Radwan et al. (2011) who indicated that potassium fertilization resulted in significant increase in tuber yield. 
Tables 6.The main effects of potassium rates and bio- $k$ fertilizer on $\mathrm{N}, \mathrm{P}$ and $\mathrm{K}$ contents of leaves and tubers of potato plants during 2016 and 2017 seasons

\begin{tabular}{|c|c|c|c|c|c|c|c|c|c|c|c|c|c|}
\hline \multirow[b]{2}{*}{ Characters } & \multirow[t]{2}{*}{ Treatments } & \multicolumn{2}{|c|}{$\begin{array}{c}N \text { of leaves } \\
(\%)\end{array}$} & \multicolumn{2}{|c|}{$\begin{array}{c}\mathrm{N} \text { of tuber } \\
(\%)\end{array}$} & \multicolumn{2}{|c|}{$\begin{array}{c}\text { P of leaves } \\
(\%)\end{array}$} & \multicolumn{2}{|c|}{$\begin{array}{c}\text { P of tuber } \\
(\%)\end{array}$} & \multicolumn{2}{|c|}{$\begin{array}{c}\text { K of leaves } \\
(\%)\end{array}$} & \multicolumn{2}{|c|}{$\begin{array}{c}\text { K of tuber } \\
(\%)\end{array}$} \\
\hline & & 2016 & 2017 & 2016 & 2017 & 2016 & 2017 & 2016 & 2017 & 2016 & 2017 & 2016 & 2017 \\
\hline \multirow{4}{*}{ 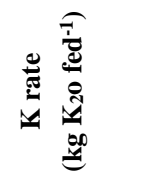 } & $\mathbf{0}$ & $3.51 \mathrm{D}$ & $3.47 \mathrm{C}$ & $2.27 \mathrm{C}$ & $2.09 \mathrm{C}$ & $0.464 \mathrm{D}$ & $0.432 \mathrm{D}$ & $0.297 \mathrm{D}$ & $0.269 \mathrm{D}$ & $2.17 \mathrm{D}$ & $2.06 \mathrm{C}$ & $1.32 \mathrm{C}$ & $1.26 \mathrm{D}$ \\
\hline & 32 & $4.68 \mathrm{C}$ & $4.52 \mathrm{~B}$ & $2.66 \mathrm{~B}$ & $2.45 \mathrm{~B}$ & $0.642 \mathrm{C}$ & $0.607 \mathrm{C}$ & $0.450 \mathrm{C}$ & $0.407 \mathrm{C}$ & $2.73 \mathrm{C}$ & $2.56 \mathrm{~B}$ & $1.74 \mathrm{~B}$ & $1.66 \mathrm{C}$ \\
\hline & 64 & $5.23 \mathrm{~B}$ & $5.06 \mathrm{~A}$ & $2.86 \mathrm{~A}$ & $2.63 \mathrm{~A}$ & $0.774 \mathrm{~B}$ & $0.741 \mathrm{~B}$ & $0.608 \mathrm{~B}$ & $0.535 \mathrm{~B}$ & $3.04 \mathrm{~B}$ & $2.84 \mathrm{~A}$ & $2.04 \mathrm{~A}$ & $1.92 \mathrm{~B}$ \\
\hline & 96 & $5.35 \mathrm{~A}$ & $5.17 \mathrm{~A}$ & $2.90 \mathrm{~A}$ & $2.67 \mathrm{~A}$ & $0.809 \mathrm{~A}$ & $0.774 \mathrm{~A}$ & $0.631 \mathrm{~A}$ & $0.567 \mathrm{~A}$ & $3.09 \mathrm{~A}$ & $2.89 \mathrm{~A}$ & $2.08 \mathrm{~A}$ & $1.97 \mathrm{~A}$ \\
\hline Bio-K & Uninoculated & $4.10 \mathrm{~B}$ & $4.00 \mathrm{~B}$ & $2.46 \mathrm{~B}$ & $2.27 \mathrm{~B}$ & $0.632 \mathrm{~B}$ & $0.597 \mathrm{~B}$ & $0.458 \mathrm{~B}$ & $0.406 \mathrm{~B}$ & $2.57 \mathrm{~B}$ & $2.38 \mathrm{~B}$ & $1.57 \mathrm{~B}$ & $1.50 \mathrm{~B}$ \\
\hline fertilizer & Inoculated & $5.28 \mathrm{~A}$ & $5.11 \mathrm{~A}$ & $2.88 \mathrm{~A}$ & $2.65 \mathrm{~A}$ & $0.713 \mathrm{~A}$ & $0.679 \mathrm{~A}$ & $0.535 \mathrm{~A}$ & $0.483 \mathrm{~A}$ & $2.94 \mathrm{~A}$ & $2.79 \mathrm{~A}$ & $2.02 \mathrm{~A}$ & $1.90 \mathrm{~A}$ \\
\hline
\end{tabular}

*Values having a common alphabetical letter (s), do not significant differ using the revised L.S.D. test at 0.05.

Tables 7. The interaction effects of potassium and bio- $k$ fertilizer on the chemical contents of leaves and tuber of potato plants during 2016 and 2017 seasons

\begin{tabular}{|c|c|c|c|c|c|c|c|c|c|c|c|c|c|}
\hline \multirow{2}{*}{$\begin{array}{c}\text { Treatment } \\
\mathbf{K}_{2} \mathrm{O} \\
(\mathrm{kg} / \mathrm{fed})\end{array}$} & \multirow{2}{*}{$\underbrace{\text { Characters }}_{\text {Bio-K }}$} & \multicolumn{2}{|c|}{$\begin{array}{c}\begin{array}{c}N \text { of leaves } \\
(\%)\end{array} \\
\end{array}$} & \multicolumn{2}{|c|}{$\begin{array}{c}\text { N of tuber } \\
(\%)\end{array}$} & \multicolumn{2}{|c|}{$\begin{array}{c}\text { P of leaves } \\
(\%)\end{array}$} & \multicolumn{2}{|c|}{$\begin{array}{c}\text { P of tuber } \\
(\%)\end{array}$} & \multicolumn{2}{|c|}{$\begin{array}{c}\text { K of leaves } \\
(\%)\end{array}$} & \multicolumn{2}{|c|}{$\begin{array}{c}\text { K of tuber } \\
(\%)\end{array}$} \\
\hline & & 2016 & 2017 & 2016 & 2017 & 2016 & 2017 & 2016 & 2017 & 2016 & 2017 & 2016 & 2017 \\
\hline \multirow{4}{*}{$\mathbf{0}$} & Without & $325 \mathrm{G}$ & $315 \mathrm{~F}$ & 2.15 & 1.96 & $0444 \mathrm{~F}$ & 0.409 & 0.280 & 0.251 & 2.07 & 1.96 & 1.19 & 1.16 \\
\hline & Bio-K & 5.250 & J.1J & $\mathrm{F}$ & $\mathrm{F}$ & $0.444 \Gamma$ & $\mathrm{E}$ & $\mathrm{E}$ & $\mathrm{E}$ & $\mathrm{F}$ & $\mathrm{G}$ & $\mathrm{F}$ & $\mathrm{G}$ \\
\hline & With Bio-K & $377 \mathrm{~F}$ & 3.80 & 2.41 & 2.23 & $0485 \mathrm{~F}$ & 0.456 & 0.316 & 0.288 & 2.28 & 2.17 & 1.45 & 1.36 \\
\hline & 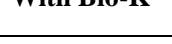 & 3.171 & $\mathrm{E}$ & $\mathrm{E}$ & $\mathrm{E}$ & 0.7051 & $\mathrm{E}$ & $\mathrm{E}$ & $\mathrm{E}$ & $\mathrm{E}$ & $\mathrm{F}$ & $\mathrm{E}$ & $\mathrm{F}$ \\
\hline \multirow{4}{*}{32} & Without & 4.03 & 3.82 & 2.40 & 2.25 & 0.604 & 0.567 & 0.409 & 0.353 & 2.52 & 2.33 & 1.49 & 1.45 \\
\hline & Bio-K & $\mathrm{E}$ & $\mathrm{E}$ & $\mathrm{E}$ & $\mathrm{E}$ & E & D & $\mathrm{D}$ & D & $\mathrm{D}$ & $\mathrm{E}$ & E & $\mathrm{E}$ \\
\hline & With Rio & 5.34 & 5.11 & 2.89 & 2.66 & 0.682 & 0.646 & 0.490 & 0.443 & 2.94 & 2.79 & 1.99 & 1.87 \\
\hline & WIIn Blo-K & $\mathrm{B}$ & $\mathrm{B}$ & $\mathrm{B}$ & $\mathrm{B}$ & $\mathrm{D}$ & $\mathrm{C}$ & $\mathrm{CD}$ & $\mathrm{C}$ & $\mathrm{B}$ & $\mathrm{B}$ & $\mathrm{B}$ & $\mathrm{B}$ \\
\hline \multirow{4}{*}{64} & Without & 4.44 & 4.36 & 2.59 & 2.40 & 0.739 & 0.695 & 0.540 & 0.489 & 2.78 & 2.56 & 1.74 & 1.60 \\
\hline & Bio-K & $\mathrm{D}$ & $\mathrm{D}$ & $\mathrm{D}$ & $\mathrm{D}$ & $\mathrm{C}$ & $\mathrm{C}$ & $\mathrm{C}$ & $\mathrm{BC}$ & $\mathrm{C}$ & $\mathrm{D}$ & $\mathrm{D}$ & $\mathrm{D}$ \\
\hline & With Bio-K & 6.03 & 5.77 & 3.1 & 2.86 & $0.810 \mathrm{~A}$ & 0.786 & 0.647 & 0.582 & 3.30 & 3.12 & 2.35 & 2.20 \\
\hline & , WIIIC DIO-K & A & $\mathrm{A}$ & $\mathrm{A}$ & $\mathrm{A}$ & $\mathrm{B}$ & $\mathrm{AB}$ & $\mathrm{AB}$ & $\mathrm{AB}$ & $\mathrm{A}$ & $\mathrm{A}$ & $\mathrm{A}$ & A \\
\hline \multirow{4}{*}{96} & Without & 4.71 & 4.58 & 2.69 & 2.48 & 0.742 & 0.719 & 0.573 & 0.514 & 2.93 & 2.69 & 1.87 & 1.77 \\
\hline & Bio-K & $\mathrm{C}$ & $\mathrm{C}$ & $\mathrm{C}$ & $\mathrm{C}$ & $\mathrm{C}$ & $\mathrm{BC}$ & $\mathrm{BC}$ & $\mathrm{BC}$ & $\mathrm{B}$ & $\mathrm{C}$ & $\mathrm{C}$ & $\mathrm{C}$ \\
\hline & With Bio-K & 6.01 & 5.76 & 3.12 & 2.85 & 0.877 & 0.830 & 0.688 & \multirow{2}{*}{$0.62 \mathrm{~A}$} & 3.26 & 3.09 & 2.30 & 2.16 \\
\hline & & A & A & A & A & A & A & A & & A & A & A & A \\
\hline
\end{tabular}

\footnotetext{
*Values having a common alphabetical letter (s), do not significant differ using the revised L.S.D. test at 0.05.
} 

photosynthesis, regulation of opening and closing of stomata, favors high energy status which helps in timely and appropriate nutrient translocation and water absorption by roots resulting in more availability of photosynthesis to produce more number of tubers per plant. It also decreases dark respiration leading to more deposition of photosynthesis in the tubers Havlin et al. (2005) and Patil (2011). It also agrees with the finding of Bansal and Trehan (2011) which mentioned that yield increment due to applied potassium through increasing tuber size.

\section{Effect of bio-fertilizer:}

Table (8) showed that the inoculation treatment with bio-K (potassien) caused significant increases on tuber yield plant $^{-1}\left(21.2\right.$ and $25.4 \%$ ), number of tuber plant ${ }^{-1}$ (4.5 and $4.1 \%)$ and average tuber weight (16.0 and $20.5 \%$ ), compared to the un-inoculated control, on first and second seasons, respectively. These results are in agreement with previous findings of Hammad and Abd El-Ati (1998) who found that the increase of tuber numbers per plant and tuber weight ( $\mathrm{g}$ ) may be due to microorganism's application stimulated plant roots absorption of nutrients and increased photosynthesis process which led to produce vigorous plants, numerous Stancheva et al. (1995) explained the effect of microorganisms on yield and its component may be attributed to one or more of the following factors: improving root growth, functions, enhancing mineral
The role of potassium in increasing the yield and its components because it plays an important role in tubers, bigger tuber size and total tuber yield. Similarly

uptake in the plant and producing the phytohormones indole acetic acid (IAA), gibberellins and cytokinin, these phytohormones, particularly IAA, play a crucial role in plant growth and development.

\section{Interaction effects between potassium and bio-K fertilizer:}

Table (9) indicated significant differences in tuber yield plant $^{-1}$, number of tuber plant ${ }^{-1}$, average tuber weight and tuber yield $\mathrm{fed}^{-1}$ due to the treatment combination between mineral $\mathrm{K}$ and bio-K (potassien) on both seasons compared to control treatment. The application of mineral $\mathrm{K}$ fertilizer at rate of 64 or $96 \mathrm{~kg} \mathrm{~K}_{2} \mathrm{O}$ fed $^{-1}$ combined with inoculated with bio-K (potassien) resulted in the highest significant mean values for tuber yield on both seasons. It was noticed that the highest tuber yield recorded with potato plants which received potassein as bio-K fertilizer and $\mathrm{K}$ fertilizer at rate of 64 or $96 \mathrm{~kg} \mathrm{~K}_{2} \mathrm{O}$ fed $^{-1}$ was due to the increase of average tuber weight and number of tubers plant ${ }^{-1}$ in both seasons. It could be concluded that using potassein as bio-K fertilizer had a beneficial effect in reducing the amount of mineral fertilizers added for potato production. These results are agreement with those found by Abou Zeid and Abd El-Latif (2017) and Bhattarail and Swarnima (2016) who reported that K application plays significant role in yield of potato tubers which is either due to formation of large sized tubers or increasing number of tubers per plant.

Tables 8.The main effects of potassium rates and bio- $k$ fertilizer on tuber yield and its components of potato plants during 2016 and 2017 seasons

\begin{tabular}{|c|c|c|c|c|c|c|c|c|c|}
\hline \multirow{2}{*}{ Treatments } & \multirow{2}{*}{ Characters } & \multicolumn{2}{|c|}{$\begin{array}{c}\text { Yield tuber } \text { plant }^{-1} \\
(\mathrm{~g})\end{array}$} & \multicolumn{2}{|c|}{$\begin{array}{c}\text { Number of tuber } \\
\text { plant }^{-1}\end{array}$} & \multicolumn{2}{|c|}{$\begin{array}{c}\text { Weight of tuber } \\
\text { (g) }\end{array}$} & \multicolumn{2}{|c|}{$\begin{array}{c}\text { Tuber yield } \\
\text { (ton/fed) }\end{array}$} \\
\hline & & 2016 & 2017 & 2016 & 2017 & 2016 & 2017 & 2016 & 2017 \\
\hline \multirow{4}{*}{ 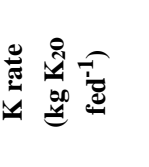 } & $\mathbf{0}$ & $549.83 \mathrm{D}$ & $534.91 \mathrm{D}$ & $5.83 \mathrm{C}$ & $5.60 \mathrm{C}$ & $94.31 \mathrm{D}$ & $95.52 \mathrm{D}$ & $9.62 \mathrm{D}$ & $9.36 \mathrm{D}$ \\
\hline & 32 & $722.87 \mathrm{C}$ & $699.00 \mathrm{C}$ & $6.27 \mathrm{~B}$ & $6.10 \mathrm{~B}$ & $115.29 \mathrm{C}$ & $114.59 \mathrm{C}$ & $12.65 \mathrm{C}$ & $12.23 \mathrm{C}$ \\
\hline & 64 & 809.19 B & $779.90 \mathrm{~B}$ & $6.66 \mathrm{~A}$ & $6.49 \mathrm{~A}$ & $121.50 \mathrm{~B}$ & $120.17 \mathrm{~B}$ & $14.16 \mathrm{~B}$ & $13.65 \mathrm{~B}$ \\
\hline & 96 & $844.87 \mathrm{~A}$ & $816.35 \mathrm{~A}$ & $6.70 \mathrm{~A}$ & $6.51 \mathrm{~A}$ & $126.10 \mathrm{~A}$ & $125.40 \mathrm{~A}$ & $14.79 \mathrm{~A}$ & $14.29 \mathrm{~A}$ \\
\hline \multirow{2}{*}{ 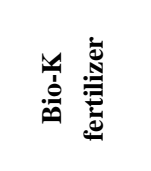 } & Uninoculated & $659.20 \mathrm{~B}$ & $625.15 \mathrm{~B}$ & $6.23 \mathrm{~B}$ & $6.05 \mathrm{~B}$ & $105.81 \mathrm{~B}$ & $103.33 \mathrm{~B}$ & $11.53 \mathrm{~B}$ & $10.94 \mathrm{~B}$ \\
\hline & Inoculated & $799.36 \mathrm{~A}$ & $784.35 \mathrm{~A}$ & $6.51 \mathrm{~A}$ & $6.30 \mathrm{~A}$ & $122.79 \mathrm{~A}$ & $124.50 \mathrm{~A}$ & 13.99A & $13.73 \mathrm{~A}$ \\
\hline
\end{tabular}

*Values having a common alphabetical letter (s), do not significant differ using the revised L.S.D. test at 0.05. 
Tables 9. The interaction effects of potassium and bio- $k$ fertilizer on tuber yield and its components of potato plants during 2016 and 2017 seasons

\begin{tabular}{|c|c|c|c|c|c|c|c|c|c|}
\hline \multirow{2}{*}{$\begin{array}{l}\text { Treatments } \\
K_{2} 0(\mathrm{~kg} / \mathrm{fed})\end{array}$} & \multirow{2}{*}{ Characters } & \multicolumn{2}{|c|}{$\begin{array}{c}\text { Yield tuber plant }^{-1} \\
(\mathrm{~g})\end{array}$} & \multicolumn{2}{|c|}{$\begin{array}{c}\text { Number of tuber } \\
\text { plant }^{-1}\end{array}$} & \multicolumn{2}{|c|}{$\begin{array}{c}\text { Weight of tuber } \\
\text { (g) }\end{array}$} & \multicolumn{2}{|c|}{$\begin{array}{c}\text { Tuber yield } \\
\text { (ton/fed) }\end{array}$} \\
\hline & & 2016 & 2017 & 2016 & 2017 & 2016 & 2017 & 2016 & 2017 \\
\hline \multirow{2}{*}{$\mathbf{0}$} & Without Bio-K & $506.89 \mathrm{G}$ & $490.56 \mathrm{G}$ & $5.77 \mathrm{~F}$ & $5.55 \mathrm{~F}$ & $87.85 \mathrm{G}$ & $88.39 \mathrm{~F}$ & $8.87 \mathrm{G}$ & $8.58 \mathrm{G}$ \\
\hline & With Bio-K & $592.53 \mathrm{~F}$ & $581.00 \mathrm{~F}$ & $5.88 \mathrm{E}$ & $5.66 \mathrm{E}$ & $100.77 \mathrm{~F}$ & $102.65 \mathrm{E}$ & $10.37 \mathrm{~F}$ & $10.17 \mathrm{~F}$ \\
\hline \multirow{2}{*}{32} & Without Bio-K & $646.99 \mathrm{E}$ & $613.98 \mathrm{E}$ & $6.11 \mathrm{D}$ & $6.00 \mathrm{D}$ & $105.89 \mathrm{E}$ & $102.33 \mathrm{E}$ & $11.32 \mathrm{E}$ & $10.74 \mathrm{E}$ \\
\hline & With Bio-K & $803.00 \mathrm{~B}$ & $789.00 \mathrm{~B}$ & $6.44 \mathrm{C}$ & $6.22 \mathrm{C}$ & $124.69 \mathrm{~B}$ & $126.85 \mathrm{~B}$ & $14.05 \mathrm{~B}$ & $13.81 \mathrm{~B}$ \\
\hline \multirow{2}{*}{64} & Without Bio-K & $715.78 \mathrm{D}$ & $672.44 \mathrm{D}$ & $6.48 \mathrm{C}$ & $6.33 \mathrm{~B}$ & $110.46 \mathrm{D}$ & 106.23 D & $12.53 \mathrm{D}$ & $11.77 \mathrm{D}$ \\
\hline & With Bio-K & $907.90 \mathrm{~A}$ & $893.24 \mathrm{~A}$ & $6.85 \mathrm{~A}$ & $6.66 \mathrm{~A}$ & $132.54 \mathrm{~A}$ & $134.12 \mathrm{~A}$ & $15.90 \mathrm{~A}$ & $15.63 \mathrm{~A}$ \\
\hline \multirow{2}{*}{96} & Without Bio-K & $779.71 \mathrm{C}$ & $736.75 \mathrm{C}$ & $6.55 \mathrm{~B}$ & $6.33 \mathrm{~B}$ & $119.04 \mathrm{C}$ & $116.39 \mathrm{C}$ & $13.64 \mathrm{C}$ & $12.89 \mathrm{C}$ \\
\hline & With Bio-K & $912.08 \mathrm{~A}$ & $900.41 \mathrm{~A}$ & $6.85 \mathrm{~A}$ & $6.70 \mathrm{~A}$ & $133.15 \mathrm{~A}$ & $134.39 \mathrm{~A}$ & $15.96 \mathrm{~A}$ & $15.75 \mathrm{~A}$ \\
\hline
\end{tabular}

*Values having a common alphabetical letter (s), do not significant differ using the revised L.S.D. test at 0.05.

\section{Tuber quality:}

\section{Effect of potassium:}

Table (10) illustrated that application of $\mathrm{K}$ fertilization significantly increased plant contents of dry matter, protein, starch and total carbohydrates as well as specific gravity compared to un-treated plants on both seasons. The high $\mathrm{K}$ rate $\left(96 \mathrm{~kg} \mathrm{~K}_{2} \mathrm{O}\right.$ fed $\left.^{-1}\right)$ gave the highest mean values for these characters on both seasons. On the other hand, the increasing $\mathrm{K}$ rate significantly decreased the reduced sugars content and the decrements was more pronounced at higher $\mathrm{K}$ rates meanwhile the control treatment $\left(0 \mathrm{~kg} \mathrm{~K}_{2} \mathrm{O}\right.$ fed $\left.^{-1}\right)$ gave the highest mean values for reducing sugars content on both seasons. The improvement of tubers quality characters expressed as dry matter, protein, starch, and total carbohydrates contents and specific gravity, as affected by increasing of mineral-K levels may be attributed to the positive effect of potassium on translocation of assimilates Marschner (1995) and Mengel (1997). Moreover Mohammad and Naseem (2006) stated that the potassium supplied with plant resulted in high nitrate reeducates activity and cause efficient formation of molecules with nitrogen in their structure which is important for synthesis of enzymes and proteins. Likewise Perrenoud (1993) concluded that potassium fully activated the enzyme system involved in starch formation which led to rapid synthesis of starch in potatoes. Also, the results of Marschner (1995) and Gerendas et al. (2007) indicated that higher doses of K lead to a lower amount of reducing sugars content since potassium application has the potential to decrease reducing sugar content of potato tubers by activating starch synthesis. Furthermore, Khan et al. (2010) found that $\mathrm{K}_{2} \mathrm{SO}_{4}$ application increases dry matter content of potato tubers.

\section{Effect of bio-fertilizer:}

Table (10) revealed significant results on tuber quality (specific gravity, dry matter content, protein contents, starch contents and total carbohydrates) in response to bio-K (potassien) application on both seasons, except reducing sugars content, the control (un-inoculated of bio-K) gave the highest mean values for reducing sugars content on both seasons. These results are in agreement with those reported by (Khan et al., 2010) who reported that bio-fertilizer application improved plant growth and dry matter production which in turn reflected on increased tuber quality of potato plants. Moreover Martin-Prevel (1989) and Marschner (1995) demonstrated that applying bio fertilizer to the soil or inoculated with tuber, increased the percentage of nutrients in potato leaves, specific gravity, dry matter content, protein contents and total carbohydrates. Also, Abdel-Salam and Shams (2012) noted that bio fertilization increased starch content in potato tuber. Similarly, Ahmed et al. (2009) indicated that the positive effect of bio-K fertilizer on the tubers quality parameters and nutritional constituents is an expected result for its effect on improving plant growth and dry matter production. 
Tables 10.The main effects of potassium rates and bio- $k$ fertilizer on tuber quality of potato plants during 2016 and 2017 seasons

\begin{tabular}{|c|c|c|c|c|c|c|c|c|c|c|c|c|c|}
\hline \multirow[t]{2}{*}{ Treatmer } & \multirow[t]{2}{*}{ Characters } & \multicolumn{2}{|c|}{$\begin{array}{c}\text { Specific } \\
\text { gravity }\left(\mathrm{g} / \mathrm{cm}^{3}\right)\end{array}$} & \multicolumn{2}{|c|}{$\begin{array}{c}\text { Dry matter } \\
(\%)\end{array}$} & \multicolumn{2}{|c|}{$\begin{array}{c}\text { Reducing } \\
\text { sugars content } \\
(\%) \\
\end{array}$} & \multicolumn{2}{|c|}{$\begin{array}{c}\text { Protein } \\
\text { contents } \\
(\%) \\
\end{array}$} & \multicolumn{2}{|c|}{$\begin{array}{c}\text { Starch } \\
\text { contents } \\
(\%) \\
\end{array}$} & \multicolumn{2}{|c|}{$\begin{array}{c}\text { Total } \\
\text { carbohydrates } \\
(\%) \\
\end{array}$} \\
\hline & & 2016 & 2017 & 2016 & 2017 & 2016 & 2017 & 2016 & 2017 & 2016 & 2017 & 2016 & 2017 \\
\hline \multirow{8}{*}{ 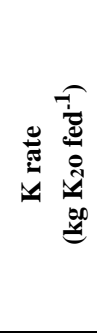 } & \multirow{2}{*}{$\mathbf{0}$} & 1.067 & 1.064 & 18.11 & 17.57 & 1.04 & 1.07 & 14.24 & 13.10 & 10.38 & 10.44 & 36.24 & 35.14 \\
\hline & & $\mathrm{D}$ & $\mathrm{D}$ & $\mathrm{D}$ & $\mathrm{D}$ & $\mathrm{A}$ & $\mathrm{A}$ & $\mathrm{C}$ & $\mathrm{C}$ & $\mathrm{D}$ & $\mathrm{C}$ & $\mathrm{D}$ & $\mathrm{D}$ \\
\hline & \multirow{2}{*}{32} & 1.078 & 1.074 & 19.97 & 19.30 & 0.94 & 0.95 & 16.54 & 15.34 & 12.93 & 12.23 & 41.11 & 39.28 \\
\hline & & $\mathrm{C}$ & $\mathrm{C}$ & $\mathrm{C}$ & $\mathrm{C}$ & B & B & B & B & $\mathrm{C}$ & B & $\mathrm{C}$ & $\mathrm{C}$ \\
\hline & \multirow{2}{*}{64} & 1.084 & 1.080 & 21.17 & 20.41 & 0.75 & 0.76 & 17.90 & 16.43 & 14.61 & 13.42 & 43.93 & 41.78 \\
\hline & & B & B & B & B & $\mathrm{C}$ & $\mathrm{C}$ & A & A & B & B & B & $\mathrm{B}$ \\
\hline & \multirow{2}{*}{96} & 1.085 & 1.081 & 21.29 & 20.60 & 0.52 & 0.56 & 18.14 & 16.68 & 14.83 & 13.60 & 44.56 & 42.34 \\
\hline & & A & A & A & A & $\mathrm{D}$ & $\mathrm{D}$ & A & $\mathrm{A}$ & A & A & A & A \\
\hline \multirow{4}{*}{ 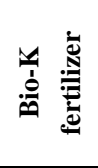 } & \multirow{2}{*}{ Uninoculated } & 1.072 & 1.068 & 18.83 & 18.04 & 0.87 & 0.87 & 15.36 & 14.22 & 11.66 & 10.86 & 38.47 & 36.88 \\
\hline & & $\mathrm{B}$ & B & B & B & $\mathrm{A}$ & $\mathrm{A}$ & B & B & B & B & B & $\mathrm{B}$ \\
\hline & \multirow{2}{*}{ Inoculated } & 1.085 & 1.081 & 21.44 & 20.90 & 0.8 & 0.8 & 18.05 & 16.56 & 14.72 & 13.99 & 44.45 & 42.39 \\
\hline & & A & A & A & A & B & B & A & A & A & A & A & A \\
\hline
\end{tabular}

*Values having a common alphabetical letter (s), do not significant differ using the revised L.S.D. test at 0.05.

Table 11.The interaction effects of potassium and bio- $\mathrm{k}$ fertilizer on tuber quality of potato plants during 2016 and 2017 seasons

\begin{tabular}{|c|c|c|c|c|c|c|c|c|c|c|c|c|c|}
\hline \multirow[b]{2}{*}{$K_{2} 0(\mathrm{~kg} / \mathrm{fed})$} & \multirow[t]{2}{*}{ Bio-K } & \multicolumn{2}{|c|}{$\begin{array}{l}\text { Specific } \\
\text { gravity } \\
\left(\mathrm{g} / \mathrm{cm}^{3}\right)\end{array}$} & \multicolumn{2}{|c|}{$\begin{array}{c}\text { Dry matter } \\
(\%)\end{array}$} & \multicolumn{2}{|c|}{$\begin{array}{c}\text { Reducing } \\
\text { sugar } \\
\text { Contents } \\
(\%) \\
\end{array}$} & \multicolumn{2}{|c|}{$\begin{array}{c}\text { Protein } \\
\text { contents } \\
(\%)\end{array}$} & \multicolumn{2}{|c|}{$\begin{array}{c}\text { Starch } \\
\text { contents } \\
(\%)\end{array}$} & \multicolumn{2}{|c|}{$\begin{array}{c}\text { Total } \\
\text { carbohydrates } \\
(\%)\end{array}$} \\
\hline & & 2016 & 2017 & 2016 & 2017 & 2016 & 2017 & 2016 & 2017 & 2016 & 2017 & 2016 & 2017 \\
\hline \multirow{4}{*}{$\mathbf{0}$} & Without & 1.063 & 1.060 & 17.3 & 16.4 & 1.071 & 1.097 & 13.4 & 12.8 & 9.6 & 9.4 & 34.58 & 33.24 \\
\hline & Bio-K & F & F & $\mathrm{G}$ & $\mathrm{F}$ & A & A & $\mathrm{G}$ & $\mathrm{G}$ & $\mathrm{H}$ & $\mathrm{H}$ & G & $\mathrm{G}$ \\
\hline & \multirow{2}{*}{ With Bio-K } & 1.071 & 1.069 & 18.9 & 18.7 & 1.016 & 1.046 & 15.0 & 13.9 & 11.1 & 11.5 & 38.14 & 37.06 \\
\hline & & $\mathrm{E}$ & $\mathrm{E}$ & $\mathrm{E}$ & $\mathrm{D}$ & $\mathrm{A}$ & $\mathrm{AB}$ & $\mathrm{E}$ & $\mathrm{F}$ & $\mathrm{E}$ & $\mathrm{E}$ & $\mathrm{E}$ & $\mathrm{E}$ \\
\hline \multirow{4}{*}{32} & Without & 1.071 & 1.066 & 18.6 & 17.8 & 0.954 & 0.950 & 14.9 & 14.1 & 11.3 & 10.6 & 37.95 & 36.12 \\
\hline & Bio-K & E & E & $\mathrm{F}$ & $\mathrm{E}$ & B & B & $\mathrm{F}$ & $\mathrm{E}$ & $\mathrm{G}$ & $\mathrm{G}$ & G & $\mathrm{G}$ \\
\hline & \multirow{2}{*}{ With Bio-K } & 1.084 & 1.081 & 21.3 & 20.8 & 0.923 & 0.953 & 18.0 & 16.6 & 14.5 & 13.8 & 44.29 & 42.11 \\
\hline & & $\mathrm{B}$ & $\mathrm{B}$ & $\mathrm{B}$ & $\mathrm{B}$ & $\mathrm{B}$ & $\mathrm{B}$ & $\mathrm{B}$ & $\mathrm{B}$ & $\mathrm{C}$ & $\mathrm{C}$ & $\mathrm{B}$ & $\mathrm{B}$ \\
\hline \multirow{4}{*}{64} & Without & 1.076 & 1.072 & 19.5 & 18.7 & 0.806 & 0.800 & 16.2 & 15.0 & 12.5 & 11.2 & 40.06 & 38.32 \\
\hline & Bio-K & $\mathrm{D}$ & $\mathrm{D}$ & $\mathrm{D}$ & $\mathrm{D}$ & $\mathrm{BC}$ & $\mathrm{C}$ & $\mathrm{D}$ & $\mathrm{D}$ & $\mathrm{F}$ & $\mathrm{F}$ & $\mathrm{D}$ & $\mathrm{D}$ \\
\hline & \multirow{2}{*}{ With Bio-K } & 1.092 & 1.088 & 22.9 & 22.1 & 0.688 & 0.725 & 19.6 & 17.9 & 16.7 & 15.4 & 47.81 & 45.25 \\
\hline & & A & $\mathrm{A}$ & $\mathrm{A}$ & $\mathrm{A}$ & $\mathrm{CD}$ & $\mathrm{C}$ & $\mathrm{A}$ & $\mathrm{A}$ & $\mathrm{A}$ & $\mathrm{A}$ & $\mathrm{A}$ & $\mathrm{A}$ \\
\hline \multirow{4}{*}{96} & Without & 1.079 & 1.074 & 20.0 & 19.3 & 0.588 & 0.621 & 16.8 & 15.5 & 13.2 & 12.0 & 41.53 & 39.52 \\
\hline & Bio-K & $\mathrm{C}$ & $\mathrm{C}$ & $\mathrm{C}$ & $\mathrm{C}$ & $\mathrm{DE}$ & $\mathrm{C}$ & $\mathrm{C}$ & $\mathrm{C}$ & $\mathrm{D}$ & $\mathrm{D}$ & $\mathrm{C}$ & $\mathrm{C}$ \\
\hline & \multirow{2}{*}{ With Bio-K } & 1.092 & 1.088 & 22.6 & 21.9 & 0.459 & 0.498 & 19.5 & 17.8 & 16.5 & 15.2 & 47.59 & 45.16 \\
\hline & & A & $\mathrm{A}$ & $\mathrm{A}$ & A & $\mathrm{E}$ & E & $\mathrm{A}$ & A & A & A & A & A \\
\hline
\end{tabular}

*Values having a common alphabetical letter (s), do not significant differ using the revised L.S.D. Test at 0.05 


\section{REFERENCES}

Abd El-Latif, K. M., E. A.M. Osmana, R. Abdullah and N. Abd el Kader. 2011. Response of potato plants to potassium fertilizer rates and soil moisture deficit. Advances in Applied Sci. Res. 2. (2): 388-397. 09768610 .

Abdel-Salam, M.A and A.S. Shams.2012. Feldspar -K fertilization of potato (Solanum tuberosum L.) augmented by biofertilizer. American- Eurasian J. Agric. Environ. Sci. 12 (6):694-699.

Abou zeid, S.T. and A. Abd El-Latif (2017). Evaluation of Potassium Sources and Rates on the Yield and Quality of Fertigated Potato Grown in Sandy Soil. Egypt. J. Soil Sci. 57: 15- 21.

Adhikary, B. H and K. B. Karki. 2006. Effect of potassium on potato tuber production in acid soils of Malepatan, Bokhara. Nepal Agric. Res. J. 7: 42-48.

Afify, A. H. and S. M. M. Bayoumy.2001. Effect of certain silicate bacteria on primary silicate minerals. Egypt J. Agric Sci., Mansoura Univ. 26(5): 3111-3125.

Ahmed, A. A., M. M. H. Abd El-Baky, F. S. Abd El-Aal and M. F. Zaki. 2009. Comparative studies of application both mineral and bio-potassium fertilizer on the growth, yield and quality of potato plant. Resrarch. J. Agric. Bio. Sci.5(6): 1061-1069. INSInet publication.

Al-Moshileh, A. M., M. A. Errebhi and M. I. Motawei. 2005. Effect of various potassium and nitrogen rates and splitting methods on potato under sandy soil and arid environmental conditions. J. Agric. Sci.17 (1): 01-09.

Al-Moshileh, A.M. and M.A. Errebi . 2004. Effect of Various Potassium Sulfate Rates on Growth, Yield and Quality of Potato Grown under Sandy Soil and Arid Conditions. IPI Regional Workshop on Potassium and Fertigation Development in West Asia and North Africa.Rabat:24-28.

Andre, C. M., M. Ghislain, P. Bertin, M. Oufir, R. Herrera Mdel, L. Hoffmann, J. F. Hausman, Y. Larondelle, and D. Evers.2007a. Andean potato cultivars (Solanum tuberosum L.) as a source of antioxidant and mineral micronutrients. J. Agric. Food Chem. 55.366-378.

Archana, D.S., M.S. Nandish, V.P. Savalagi and A.R. Alagawadi. 2012. Screening of potassium solubilizing bacteria (KSB) for plant growth promotional activity. BIOINFOLET-A Quarterly J. Life Sci. 9:627-630.

Badr, M.A., A.M. Shafei and S.S.H., El-Deen. 2006. The dissolution of $\mathrm{K}$ and P-bearing minerals by silicate dissolving bacteria and there effect on sorghum growth. Res J. Agric. Biol. Sci. 2:5-11.

Bansal S.K. and S.P. Trehan. 2011. Effect of potassium on yield and processing quality attributes of potato. Karnataka J. Agric. Sci., 24(1):48-54.

Barakat, M. A. S. and S. M. Gabr.1998. Effect of different biofertilizer types and nitrogen fertilizer levels on tomato plant. Alex. J. Agric. Res. 43 (1): 149-160.
Bednarz, C.W. and D.M. Oosterhuis. 1999. Physiological changes associated with potassium deficiency in cotton. J. Plant Nutr. 22: 303-313.

Bhattarai1, B. and K.C. Swarnima. 2016. Effect of Potassium on Quality and yield of Potato tubers - A Review. SSRG International Journal of Agriculture55 \& Environmental Science (SSRG-IJAES)-volume 3 Issue 6 Nov to Dec ISSN: 2394-2568.

Costat software. 1985. User's Manual. Version 3. Cohort. Tusson. Arizona. USA.

Deka, N.C. and T.C. Dutta. 2000. Effect of potassium on yield and economics of potato cultivation in an acidic soil of Assam.j.Potassium Res.16:77-99.

Dinesh, K., R. Ezekiel, B. Singh and I. Ahmed. 2005.2 Conversion Table for specific gravity dry matter and starch content from under water weight of potatoes grown in North India plains. Potato J. 32 (1-2) :79-84.

Dubois, M., K. A. Gullles, J. K. Hamilton, P. A. Rebers and F. Smith. 1956. Colorimetric method of determination of sugars and related substances. Analy. Chem. 28:250-356.

El-Banna, E. N. and A. F. Tolba. 2000. Effect of microbein (bio-fertilizers) and different levels of nitrogen and phosphorus on growth and yield of potato plant (Solanum tuberosum L.). J. Agric. Sci. Mansoura Univ. 25 (8):53425352.

Elhakim, S. A. Z., D. S. El-Mesirry and M. M. Yousry.2016. Impact of potassium fertilization rates and bacillus circulans on the growth, yield and color of processed potato (Solanum tuberosum L.) tubers chips. Alex. Sci. Exch. J.37:594-605.

El-Rawy, K.M. and A.M. Khalf-Allah.1980. Design and Analysis of Agricultural Experiments. Text book. ElMousil Univ. press Ninawa, Iraq.p. 487.

El-Sayed S.F., H.A. Hassan, M.M. El-Mogy and A. AbdelWahab .2014. Growth, Yield and Nutrient Concentration of Potato Plants Grown under Organic and Conventional Fertilizer Systems.Am. Eurasian J. Agric. Environ. Sci., 14(7): 636-643.

El-Shimi, A., S. A. A. Mansour and V. SH. G. Abd El-Malak. 2002. Response of two strawberry Cultivars to bio and chemical fertilizers and their effect on pests infestation. J. Agri. Sci. Mansoura Univ. 27 (12): 8547-8568.

FAO. 2009. Potato and Food Price Inflation. International Year of the Potato 2008. Food and Agriculture Organization of the United Nations, Rome.

Fawzy, Z. F., A. M. El-Bassiony, L. Yunsheng, O. Zhu and A. A. Ghoname. 2012. Effect of mineral, organic and bio-N fertilizers on the growth, yield and fruit quality of sweet pepper. J. A. Sci. Res. 8 (8): 32921-3933.

Gabr, S. M., I. M. Ghoneim and H. M. F. Hassan. 2001. Effects of bio-and nitrogen-fertilization on growth, flowrring, chemical contents, yield and quality of sweet pepper. J. Adv. Agric. Res. 6 (4): 939-955. 
Gerendas, J., F. Heuser and B. Sattlemacher.2007. Influence of nitrogen and potassium supply on contents of acrylamide precusors in potato tubers and on acrylamide accumulation in fries. J. of Plant Nutrition. 30(7): 14991516.

Ghoneim, I. M. 2005. Effect of bio- fertilizers types under varying nitrogen levels on vegetative growth, heads yield and quality of glope artichoke (Cynara scolymus, L.). J. Agric. Environ. Sci. 4: 1-23.

Hammad, A. M. M. and Y. Y. Abd El-Ati 1998. Reducing of nitrate and nitrate contents of potato tubers via biofertilization with Azospiirllum and via mycorrhizal fungi. J. Agric. Sci. Mansoura Univ. 23 (6): 2597-2610.

Han, H.S. and K.D. Lee. 2005. Phosphate and potassium solubilizing bacteria effect on mineral uptake, soil availability and growth of eggplant. Research J. Agri. Biol. Sci. 1(2):176-180.

Han, H.S. and K.D. Lee. 2006. Effect of co-inoculation with phosphate and potassium solubilizing bacteria on mineral uptake and growth of pepper and cucumber. Plant S. Environ. 52(3):130-136.

Havlin, J.L., J.D. Beaton, S.L. Tisdale and W.L. Nelson. 2005. Soil Fertility and Fertilizers: An Introduction to Nutrient Management. 7th Edition, Pearson Educational, Inc., Upper Saddle River, New Jersey.

Helal, N. A. S. and S. A. Abd Elhady.2015. Calcium and Potassium Fertilization May Enhance Potato Tuber Yield and Quality. Middle East J. Agric. Research 04: 991-998.

Horneck, D.A. and D. Hanson.1998. Determination of potassium and sodium by flame emission spectrophotometry. Handbook of reference methods for plant analysis, CRC Press Boca Raton. 19: 153-155.

Janmohammadi, M., N. Pornour, A. Javanmard and N. Sabaghnia. 2016. Effect of bio -organic, conventional and nano fertilizers on Growth, Yield and quality of potato in cold steppe. (2): 133-144.

Khan, M.Z., M.E. Akhtar, M.N. Safdar, M.M. Mahmood, S. Ahmad, and N. Ahmed.2010. Effect of source and level of potash on yield and quality of potato tubers. Pak. J. Bot. 42: 3137-3145.

Kumar, P. and R.C. Dubey. 2012. Plant Growth Promoting Rhizobacteria for Biocontrol of Phytopathogens and Yield Enhancement of Phaseolus vulgaris. J Curr Pers Appl Microbiol 1: 6-38.

Lichtenthaler, H.K. 1987. Chlorophylls and carotenoids: pigments of photosynthetic biomembranes. Methods Enzymol 148:350-382.

Lin, Q.M., Z.H. Rao, Y.X Sun, J. Yao and L.J. Xing. 2002. Identification and practical application of silicatedissolving bacteria. Agric. Sci. China 1: 81-85.

Lynn, T.M., H.S. Win, E.P. Kyaw, Z.K. Latt and SS. Yu. 2013. Characterization of phosphate solubilizing and potassium decomposing strains and study on their effects on tomato cultivation. International J. Innovation Applied Studies. 3:959-966.
Malik, C. P. and M. B. Singh.1980. Plant enzymology and histoenzymology. A Text. Manual. Kalyani Publishers, New Delhi.

Marschner, H. 1995. Mineral nutrition of higher plants. $2^{\text {nd }}$ Ed. Academic Press, London. C.F. Patricia Imas and S. K. Bansal, Potassium and Integrated Nutrient Management in Potato, IPI - International Potash Institute. Bern. pp: 1-15.

Marschner, H. 1997. Mineral nutrition of higher plants.2nd ed. Acad. Press Inc., London.

Martin-Prevel, P. J. 1989. Physiological processes related to handling and storage quality of crops. Proceedings of the 21st IPI Colloquium on: Methods of K Research in Plants 219-248. Bern, Switzerland: International Potash Institute.

Mehdi, S.M., M. Sarfraz and M. Hafeez . 2007. Response of rice advance line $\mathrm{PB}-95$ to potassium application in saline-sodic soil. Pak. J. Biol. Sci. 10: 2935-2939.

Mengel, K. 1997. Impact of potassium on crop yield and quality with regard to economic and ecological aspects. In: proceedings of the IPI Regional workshop on: Food security in the WANA Region, The Essential Need for Balanced Fertilization, held at Bornova, Izmir, Turkey, International Potash Institute. Bern, Switzerland .157-174.

Mohammad, F. and U. U. Naseem. 2006. Effect of K application on leaf carbonic anhydrase and nitrate reductase activities, photosynthetic characteristics, NPK and NO contents, growth and yield of mustard. Photosynthetica 44: 471-473.

Mohammadi, G. R., A. Rostami Ajirloo, M. E. Ghobadi and A. Najaphy. 2013. Effects of non-chemical and chemical fertilizers on potato (Solanum tuberosum L.) yield and quality. J. of Medic. Plants Res. 7(1):36-42.

Page, A., R. Miller and D. Keeneny. 1982. Methods of soil analysis. Part 2. chemical and microbiological properties. $2^{\text {nd }}$ edition. Agron. Madison. Wisconsin.USA.

Parmar, P. and S.S. Sindhu.2013. Potassium solubilization by rhizosphere bacteria: influence of nutritional and environmental conditions. J Microbiol Res 3:25-31.

Patil, R.B. 2011. Role of potassium humate on growth and yield of soybean and black gram. International J. Pharma Bio. sci. 2(1): 242-246.

Perrenoud, S. 1993. Fertilizing for higher yield potato, IPI Bull. 8, 2nd Ed. International Potash Institute. Bern, Switzerland.

Ponmurugan, P. and C. Gopi.2006. In vitro Int.J.Curr.Microbiol. App.Sci 3(5):1045-1052 1052 production of growth regulators and phosphate activity by phosphate solubilizing bacteria. African J. Biotechnol. 5: 348-350.76

Prajapati, K., M.C. Sharma and H.A. Modi. 2013. Growth promoting effect of potassium solubilizing microorganisms on okra (Abelmoscus esculantus). Internaltion J. Agric. Sci. Res. 1:181-188.

Radwan, E.A., Z.S.A. El-Shall and R.A.M. Ali. 2011. Effect of potassium fertilization and humic acid application on plant growth and productivity of potato plants under clay soil. J. Plant Production, Mansoura Univ. 2(7):877-890. 
Ramarethinam, S. and K. Chandra. 2006. Studies on the effect of Potash Solubilizing/Mobilizing Bacteria Frateuriaaurantia (Symbion-K Liquid Formulation) on brinjal (Solanumme langena) growth and yield. Pestology. 30(11):35-39.

Rogers, J.R., P.C. Bennett and W.J Choi. 1998. Feldspars as a source of nutrients for microorganisms. Am. Mineralogy. 83: $1532-1540$

Salami, M. and S. Saadat. 2013. Study of potassium and nitrogen fertilizer levels on the yield of sugar beet in jolge cultivar. J. Novel Applied Sci. 2(4):94-100.

Sangeeth, K.P., R.S. Bhai and V. Srinivasan. 2012. Paenibacillus glucanolyticus, a promising potassium solubilizing bacterium isolated from black pepper (Piper nigrum L.) rhizosphere. J. Spice and Aromatic Crop. 21(2):118-124.

Sheng, X. F. and L. Y. He. 2006. Solubilization of potassium bearing minerals by a wild type strain of Bacillus edaphicus and its mutants and increased potassium uptake by wheat. Can. J. Microbial., 52(1): 66- 72.

Sheng, X.F., W.Y. Huang and Y.X. Yin. 2003.15 Effects of application of silicate bacteria fertilizer and its potassium release. J. Nanjing Agric. Univ. 23: 43-46.15.

Singh, D., P. K. Chhonker and B. S. Dwivedi. 2005. Manual on soil plant and water analysis. West Ville publishing house, New Delhi: 200.
Singh, J. and S.K. Bansal. 2000. Relative effect of two sources of potassium on yield and economics of potatoproduction in an Inceptisol of western UP. J. of Potassium Res. 16: 52-54.

Singh, S. K and S. S. Lal . 2012. Effect of potassium nutrition on Potato yield, quality and nutrient use efficiency under varied levels of nitrogen application. Pot. J. 39 (2): 155165.

Stancheva, I., I. Dimitrov, N. Kaloyanova, N. Dinev and N. Poushkarov. 1995. Improvement of the nitrogen uptake and nitrogen content in maize (Zea mays) by inoculation with Azospirillum brasilense. Agrochimica. 39: 299-306.

Wallingford, W. 1980. Function of potassium in plants In: Potassium for Agriculture. Potash and Phosphate Inst., Atlanta. Georgia. pp: 10-27.

Wang, M., Q. Zheng, Q. Shen and S. Guo. 2013. The critical role of potassium in plant stress response. Intern. J. Molecular sci., 14(4):7370-7390.

Westermann, D.T., D.W. James, T.A. Tindall and R.L Hurst.1994. Nitrogen and potassium fertilization of potatoes: Sugars and starch. Am. Potato J. 71:433-452.

Xue, Q.H., J.W. Sheng and L. Tang. 2000. Effect of K bacteria on nutrients activation in Lou Soil Acta, Agriculture Boreali-Occidentalis Sinica, 9(3): 67-71. 


\section{الملخص العربي}

تأثير استخدام مستويات مختلفة من التسميد البوتاسي مع التلقيح بالبكتيريا المذيبه للبوتاسيوم على نمو ومحصول وجوده البطاطس معن

حسن احمد الخطيب و سعيد محمد جبر و رمضان عبد العاطى محمد واحمد فؤاد مناع وجده

أدت أيضا الى تحسين جوده الدرنات التي يتم التعبير عنها

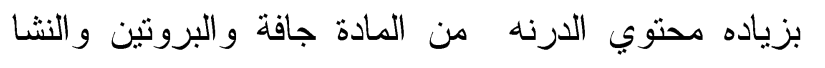
و الكربو هيدرات وكذلك زيادة الكثافه النوعيه لللدرنه في كلا من موسمي النمو. وتوضح الدراسه أن تأثير التداخل بين مستوى التسميد

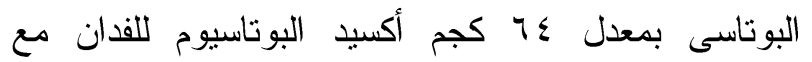

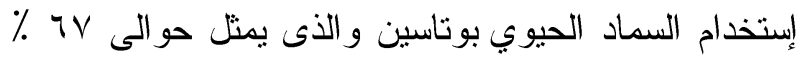

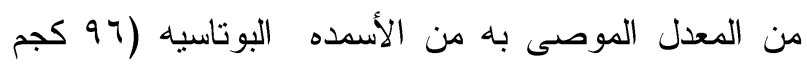

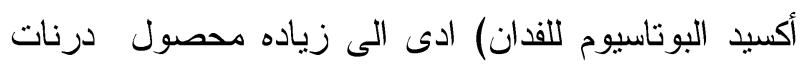

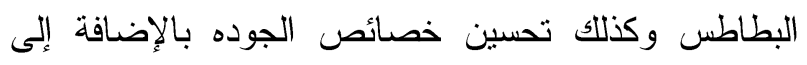
توفير حوالي بس ٪ من إحتياجات البطاطس من الأسمدة البوتاسيه.
أجرئيث دراسة حقلّية لمدة عاميّن خلال الموسم الصُّيفَ

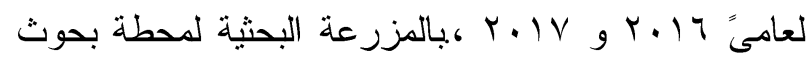

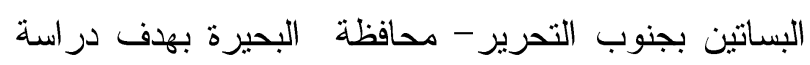

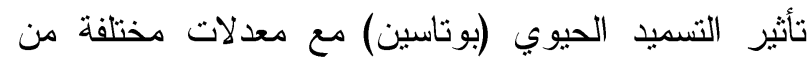

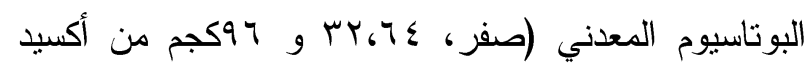
البوتاسيوم للفدان) على النمو والمحصول والجوده لنباتات

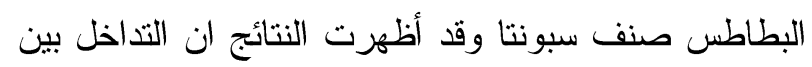

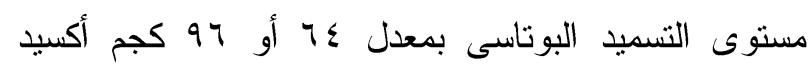

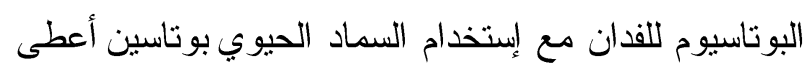

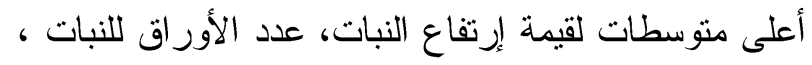

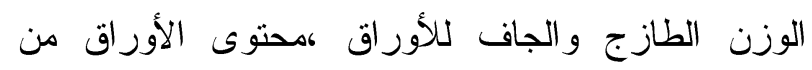
الكلوروفيل وكذلك زياده محتوى الأوراق و الدرنات من الأن

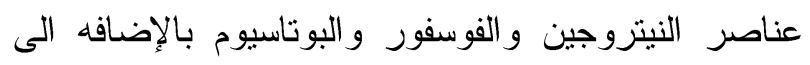
زيادة المحصول الكلى للفدان ومتوسط وزن ولئون الدرنه وكما 